\title{
Impact of Classroom Environment on Students` Performance in English Language
}

\author{
Dr. Yagana S. WALI Dr. Fathi Ahmad ABULFATHI Muhammad Ali MUSTAPHA \\ Department of Arts Education, University of Maiduguri, P.M.B. 1069, Maiduguri
}

\begin{abstract}
The objectives of the study are to examine impact of classroom environment on the academic performance of students in English language as well as their performance difference by gender. Survey and Correlation research designs were employed. The population of the study involved 183 teachers and 2003 SS III students in the selected schools. 401 students representing $20 \%$ and 183 teachers were randomly selected. Self-developed questionnaire and profoma were used for collection of data for this study. The data collected were analysed using descriptive statistics of Mean and Standard Deviation and Multiple Regression Analysis. The findings of the study revealed that classroom environment has strong impact on the academic performance of students in English language. On the gender basis, there was no significant difference in the performance of students. Therefore, it was recommended that school management should provide all necessary facilities in the classroom in order to create enabling environment for students overall development.
\end{abstract}

Keywords: Classroom Environment, Students`Academic Performance \& English Language

DOI: $10.7176 / \mathrm{JEP} / 10-17-07$

Publication date: June $30^{\text {th }} 2019$

\section{Introduction}

Without doubt, the quality of education is firmly linked to the effective coordination of the classroom environment. It is believed that a well-designed classroom will not only help to achieve the expected learning outcomes of education but also ensures cordial student-teacher relationship. The provision of sufficient learning facilities and instructional materials within suitable classroom atmosphere are some of the factors that improve the standard of education in schools.

Classroom physical environment is seen as the physical characteristics of classroom that involve different things like size of classroom, floor, walls, desks, lighting, school structure, school climate and computer. According to Suleman and Hussain (2014) physical environment is the physical aspect of the learning setting. The component of the physical environment of classroom include learners, teachers and the facilities (Lippman, 2010). Moreover, physical facilities in the ideal classroom plays a vital role in composing a strategic factor in the operation and functioning of the teaching and learning as they determine the excellent performance of a school. Physical facilities are one of the stimulating factors that play a fundamental role in improving academic achievement in the school system (Basit, 2005).

The quality of the physical classroom setting significantly affects academic achievement of the students. Physical facilities in classrooms ensure effective and successful teaching learning process. Without these facilities, effective teaching learning process cannot be guaranteed. Students tend to get more details from their instructors in a well facilitated classrooms and therefore they perform in a good way. On the other hand, if classroom setting in not conducive, students feel uncomfortable in classroom then they tend to be giving divided or distracted attention to the lesson. Lyons (2001) opined that poor facilities in school has negative impact on the teachers' effectiveness as well as students` performance.

Empirical studies on the classroom environment revealed that physical arrangement of the classroom has a significant role in teaching learning process. It can affect the performance of both the teachers and the students. Umar (2015) found that school environment as portrayed in the design, desks' arrangement and books availability in the classroom firmly associated with the performance of learners in English language. Researchers like Lyons (2001), Tylor and Vlastos (2009) reported that classroom with large class size poses a difficult condition for students to focus and therefore minimize the duration teachers can use in actual instruction of learners. Chuma (2012) reported that crowd within a classroom delays teaching-learning process. This is because the teacher may not find it easy to move around the classroom to offer individualized attention to some students sitting in the rare angles of the classroom. Adequate and sufficient arrangement of classroom environment plays a significant role in enabling instructional process more effective and establishes an optimum atmosphere for both learners and the teachers.

On the similar dimension, Asiyai (2014) reports that the classroom environment has a significant impact on the motivation and learning of students including. Maxwell (2016) also found that the students' performance is connected to the building condition mediated by social climate and student attendance. Suleman \& Hussain (2014) opined that a well-managed and vibrant classroom environment makes a positive impact on the academic performance of students. Turano (2005) also reports that students and teachers in conducive classroom 
environment tend to perform well. Suleman \& Hussain (2014) examined effect of classroom physical environment and the performance of control and experimental groups. The findings revealed that the students of experimental group showed better performance as compared to the students of control group. Sang (2013) established that pupil's text book ratio and the classroom size were the major contributors to poor performance in mathematics within pioneer zone. Umar (2017) found that classroom environment has strong influence on the academic performance of the students.

\section{Statement of the Problem}

The increasingly high rate of students` enrolment in Nigeria and the declining rate of the academic performance in public schools has for a long time been an issue of concern to government, parents and the general public. The drastically falling standard of education in schools as reflected by the failure of students in examinations including WAEC and NECO cannot be overemphasized. Many researchers have adventured into investigating the presumable causes of the students` poor performance in schools including home background, socioeconomic status, ethnicity, leadership behaviour in school, peer pressure and teacher quality. Few studies, however, conducted to examine the link of environmental variables to students academic performance were mostly home environment related researches or teacher-related ones. Although classroom environment variables can have an impact on various components of the teaching and learning processes, no significant amount of studies were conducted in the study area to determine whether or not the classroom physical environment impinges on the academic performance of students in English language. Therefore, there is a pressing need for a research into how classroom environment link to the academic performance of Senior Secondary School students in English in Maiduguri Metropolis, Borno State, Nigeria.

\section{Objectives of the Study}

The objectives of the study were to examine:

1. impact of classroom environment on the academic performance of senior secondary school students in English language

2. impact of classroom physical environment on the academic performance of Senior Secondary School students in English by gender

\section{Hypotheses}

The following hypotheses were tested

$\mathrm{H}_{\mathrm{o} 1}$ : classroom environment does not affect the academic performance of Senior Secondary School students in English language

$\mathrm{H}_{02}$ : classroom environment does not affect the academic performance of Senior Secondary School students in English language by gender

\section{Scope of the Study}

This study dealt with impact of classroom environment on the academic performance of Senior Secondary School students in English language in Maiduguri Metropolis, Borno State, Nigeria. The study focused on classroom physical environment such classroom arrangement, facilities and instructional materials in relation to the academic performance of Senior Secondary School Three (SS III) in selected public schools in Maiduguri.

\section{Methodology}

Survey and correlation research designs were employed to carry out this study. The population for the study comprised all teachers and Senior Secondary School three students of six randomly selected schools in Maiduguri Metropolis. At the time of gathering this report, there are 183 teachers and 2003 SS III students in the selected schools. 401 students representing $20 \%$ and 183 teachers were randomly selected. Self-developed Questionnaire and profoma were used for collection of data for this study. Descriptive statistics of mean and standard deviation and multiple regression were used to analyse the data.

\section{Results}

The hypotheses were tested using two statistical tools at 0.05 level of significance.

Hypothesis One: Classroom environment does not affect the academic performance of Senior Secondary School Students

To test, the hypothesis, descriptive statistics of mean and standard deviation and regression were conducted to determine the impact of classroom physical environment on students 'academic performance. 
Table 1: Descriptive Statistics on Classroom Physical Environment and Students`Academic Performance.

\begin{tabular}{lrrr} 
& Mean & Std. Deviation & N \\
\hline Students`Academic Performance & 53.68 & 8.160 & 401 \\
Classroom Physical Environment & 35.80 & 3.561 & 183 \\
\hline
\end{tabular}

Table 1 presented mean and standard deviation of classroom environment and academic performance of senior secondary school students. The table showed that the Mean $(\mathrm{M}=53.68, \mathrm{SD}=8.160)$ and Mean $(\mathrm{M}=35.80$, $\mathrm{SD}=3.561$ ) represent the Mean of students` academic performance and classroom environment to determine the level of the impact. The result indicated positive impact of classroom environment on students' academic performance.

Table 2 Multiple Regression

\begin{tabular}{llrrrr}
\hline Model & R & R Square & \multicolumn{1}{c}{ Adjusted R Square } & Std. Error of the Estimate & Sig. \\
\hline $\mathbf{1}$ & $.179^{\mathrm{a}}$ & .032 & .027 & 8.050 & 0.015 \\
\hline
\end{tabular}

Table 2 presents the multiple regression on classroom environment and students ' academic performance. The results indicated that $27 \%$ of the variation of the students' academic performance is determined and predicted by classroom environment. The results indicated that there is significant impact of classroom environment on the academic performance of the students. Therefore, the null hypothesis was rejected.

Hypothesis Two: Classroom Environment and Students`Academic Performance by Gender The null hypothesis was tested at 0.05 level of significance using descriptive statistics (Mean and Standard Deviation) and Multiple Regression.

Table 3 Descriptive Statistics

\begin{tabular}{lrrr}
\hline & Mean & Std. Deviation & N \\
\hline Students`Academic Performance & 53.68 & 8.160 & 401 \\
Students Gender & 69.44 & 8.218 & 183 \\
\hline
\end{tabular}

Table 3 presents mean and standard deviation of students' gender and the academic performance of Senior Secondary School students. The table showed that the Mean $(M=53.68, S D=8.160)$ and Mean $(M=69.44$, $\mathrm{SD}=8.218$ ) represent the Mean of students' academic performance and gender of the students. The result indicated that there is no significant difference in the performance of male and female students.

Table 4 Multiple Regression

\begin{tabular}{llrrr}
\hline Model & $\mathbf{R}$ & \multicolumn{1}{c}{ R Square } & Adjusted R Square & \multicolumn{1}{c}{ Std. Error of the Estimate } \\
\hline $\mathbf{1}$ & $.124^{\mathrm{a}}$ & .015 & .010 & 8.120
\end{tabular}

Table 4 presents multiple regression on the impact of gender on the academic performance of students in Senior Secondary School. The results indicated that $10 \%$ of the variance in the academic performance of students is predicted and determined by the students`gender. This means gender of the students has little impact on the academic performance of students. Thus, the null hypothesis was rejected.

\section{Conclusion}

Based on the findings of the study, it was concluded that classroom environment has a strong impact on the academic performance of students in English language. This might be due to the fact that when an optimum environment is enabled by the school, both students and teachers tend to be motivated and inspired toward teaching and learning. In terms of attendance rate, schools with suitable learning environment will record high rate of students' attendance as learners feel enthusiastic to be attending and participating in all academic and extra-curricular activities.

\section{Recommendations}

Based on the findings of the study, the following recommendations were made:

1. School management should provide all necessary facilities in the classroom in order to create enabling environment for students overall development.

2. School authorities should put into consideration the circumstances whereby large number of students may be enrolled due to the earnest demand of people for education. Thus, spacious classes with adequate equipment should be provided in each school.

\section{References}

Asiyai, R. (2014). Students' perception of the condition of their classroom physical learning environment and its impact on their learning and motivation. College Student Journal, 48(4), 716-726.

Asiyai, R. I. (2004). Examination malpractice in institutions of higher learning in Nigeria: The way forward. Journal of Research in Education 1(1), 20-24.

Basit, A. (2005). Classroom Management Techniques at Secondary Level and Developing a Model for Urban Schools for District Peshawar. M.Phil Thesis, Faculty of Education, Allama Iqbal Open University 
Islamabad. pp. 16-17

Chuma, P. C. (2012). Challenges Affecting Teaching-Learning in Primary Schools in Kenya. A case study of Central Division Mandera East District Executive Med Project, Moi University.

Lippman, P. C. (2010). Can the physical environment have an impact on the learning environment? CELE Exchange 2010/13 ISSN 2072-7925, (C) OECD 2010.

Lyons, J. B. (2001). Do school facilities really impact a child's education. CEFPI Brief Issue Trak, 1-6.

Maxwell, L. E. (2016). School building condition, social climate, student attendance and academic achievement: A mediation model. Journal of Environmental Psychology, 46, 206-216.

Sang, C. J. (2013) EfFect of Classroom Environment on Academic Performance in Mathematics of Preschool Children in Pioneer Zone, Uasin Gishu County, Kenya. A Research Project submitted to the Department of Educational Communication and Technology, University of Nairobi

Suleman, Q. \& Hussain, I. (2014) Effects of Classroom Physical Environment on the Academic Achievement Scores of Secondary School Students in Kohat Division, Pakistan. International Journal of Learning and Development. Vol 4, No 1

Taylor, A. and Vlastos. (2009). Linking Architecture and Education: Sustainable Design for learning Environments. Albuquerque: University of New Mexico Press.

Turano, A. A. (2005) the impact of classroom environment on student learning. Theses and Dissertations

Umar, A. (2015). Use of Mind maps in Teaching Reading for ESP Students: A Case Study of the Preparatory Students at UQU.

Umar, A. (2017) the Effect of Classroom Environment on Achievement in English as a Foreign Language (EFL): A Case Study of Secondary School Students in Gezira State: Sudan. World Journal of English Language. Vol. 7, No. 4. 